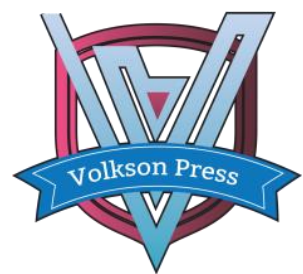

Contents List available at VOLKSON PRESS

\title{
Innovation of the economies of European Union countries against selected countries in the world in the years 2007-2016
}

\author{
Anna Kowalska1, Agnieszka Tarnowska1,* \\ ${ }^{1}$ Department of Management and Food Economy, Wroclaw University of Economics, \\ 118/120 Komandorska St, 53-345 Wroclaw, Poland \\ *agnieszka.tarnowska@ue.wroc.pl \\ This is an open access article distributed under the Creative Commons Attribution License, which permits unrestricted use, distribution, and reproduction in any \\ medium, provided the original work is properly cited.
}

\section{ARTICLE DETAILS}

\section{Article History:}

Received 02 october 2017

Accepted 06 october 2017

Available online 11 october 2017

Keywords:

Innovation, Economy, European

Union, Competitiveness.

\section{ABSTRACT}

Innovation is of great importance in the economy today. The competitiveness of economies depends on the skillful implementation of innovation. The aim of the article was to assess the innovative position and ability to implementation of innovative solutions in the EU economy against the background of the countries - the world's leaders in innovation. Numerous statistical methods have been used to determine the innovative positions and pace of their change in 35 countries. Studies have shown that the European Union is generally below the average for all countries surveyed. However, it is comprised of many countries that occupy the top positions in the innovation ranking separately. Switzerland is the undisputed leader of innovation.

\section{Introduction}

For many years, innovation has been an important area of research for global economists. The popularity of this topic is due to the growing importance of innovation for the economy. On a macroeconomic scale, innovation is a major factor in a country's economic growth. On the other hand, from the perspective of microeconomics, the implementation of innovation enables, among other things, to reduce production costs, improve quality, respond faster to buyers' expectations, better meet consumer needs, expand the range of products offered by companies, reduce ecological hazards, reduce raw material and energy consumption [1].

It is very important nowadays to be competitive and innovative. This means not only keeping up with changes, but also creating them. This applies to both companies and countries. Countries, by pursuing proinnovation policies and by distributing public finance, largely determine the level of enterprise innovation [2], [3].

According to the 1994 edition of The World Competitiveness Report, the competitiveness of the economy is a term that signifies "the ability to create greater wealth than the world's competitors" [4]. In turn, the concept of the innovation of the economy means the ability and motivation of economic operators to pursue activities aimed at improving and developing production, introducing new solutions or enhancing efficiency through research, R \& D works or searching for new concepts and ideas [5], [6].

According to K. Krzyżanowska [2008] the current stage of civilization development is an economy based on knowledge and highly developed technologies [7]. Success will be achieved by those states that will be able to continually generate innovation. Businesses' actions towards innovation can enhance the competitiveness of the given country economy against other countries. Therefore, one of the main objectives of EU economic policy is to promote and support innovative activities of member states. The impact of innovation on the country's economic development is also evident in empirical studies showing a statistically significant relationship between the size of innovation and the level of economic development achieved by the country [8].

\section{Purpose, scope and methodology of research}

The aim of this article is to assess the innovativeness of the economies of the European Union countries against the background of selected countries by means of synthetic indicators, and to show the changes that took place in this area in 2007-2016. The analysis covered 35 countries: all members of the European Community and world innovators (Switzerland, USA, Japan, Norway, Singapore, Republic of Korea, Hong Kong and Iceland).

The study of the economies' innovation was based on the measurement of factors that stimulate the increase in the level of innovation and the indicators that determine the effects of proinnovative actions. The level of innovation was calculated using the latest statistics available from Eurostat, the Organization for Economic Co-operation and Development (OECD) and the Office for Harmonization in the Internal Market (OHIM). The innovation analysis of individual world economies was based on the reports of The Global Innovation Index 2007-2016. Thanks to them The Global Innovation Index (GII) was calculated. It shows the level of innovation of most countries in the world.

GII was created in 2007 through the collaboration of the Cornwall University, the INSEAD Business School and the World Intellectual Property Organization. GII is a measure of the level of innovation in each country. The value of this index since 2011 is in the range $0-100$ (where 100 stands for the highest achievable level of innovation). There were 128 economies analyzed using the GII in 2016. The index is an average of 82 factors belonging to two groups:

Factors describing an environment conducive to innovation. The 5 most important areas of creation of innovativeness called "innovation input" are: institutions (the political, regulatory and business environment); human potential (lower and higher education, research and development); infrastructure (ICT, energy, infrastructure); advancement of the market (loans, investments as well as trade and competition) and advancement and quality of business activity (research workers, innovation partnerships, knowledge absorption).

Results measuring specific performance in terms of innovation, known as "innovation output", i.e. scientific results (knowledge creation, influence of knowledge and its dissemination) and creative (creative processes and products and services).

On this basis, groups of similar countries were also distinguished using Ward's taxonomy. Standard deviation (S (x)) was used in relation to the mean $(\bar{x})$ as a measure of the variance between the states analyzed in 
order to compare the index of innovation over time. After calculations for all analyzed variables, there were distinguished groups of countries which differed significantly in the level of the examined feature with respect to its average level in a given year. The figures above the average for a given year were divided into the following groups [9]:

- $\quad$ group 1: $<\bar{x}, \bar{x}+1 \times \mathrm{S}(x))$,

- $\operatorname{group} 2:<\bar{x}+1 \times \mathrm{S}(x), \bar{x}+2 \times \mathrm{S}(x))$,

- group 3: $<\bar{x}+2 \times \mathrm{S}(x), \bar{x}+3 \times \mathrm{S}(x))$ and further as needed;

whereas the figures below the average for a given year were divided into:

- $\operatorname{group}-1:(\bar{x}, \bar{x}-1 \times \mathrm{S}(x)>$,

- group - 2: $(\bar{x}-1 \times \mathrm{S}(x), \bar{x}-2 \times \mathrm{S}(x)>$,

- group - 3: $(\bar{x}-2 \times \mathrm{S}(x), \bar{x}-3 \times \mathrm{S}(x)>$ and further as needed.

The results were sorted to identify the countries that stand out for the largest and smallest levels of the phenomenon over the period under consideration. The number of groups separated in a given year depends on the variability of the phenomenon under investigation. In order to complete the analyses, there was used one of hierarchical cluster analysis method - the Ward method. This method was used to divide countries into similar groups in terms of the index of innovation. In this method, the variance analysis is used to estimate the distance between clusters [10].

\section{Results}

The analysis shows, that in the years 2007-2016 the average innovation index for the European Union totally was the lowest in all of this period against the background of the analysed country, which belongs to world innovators (figure 1). By 2012 its value was growing, and then there was a slight decrease. Since then, this index has remained in the EU at a similar level. For such a low its value for EU are responsible primarily countries that joined the Community in 2004 and later.

The leader of innovation in the world economies is Switzerland, which has continuously reached the highest value of the discussed index since 2010. The upward trend in the value of innovation index is also visible in the USA and Japan.

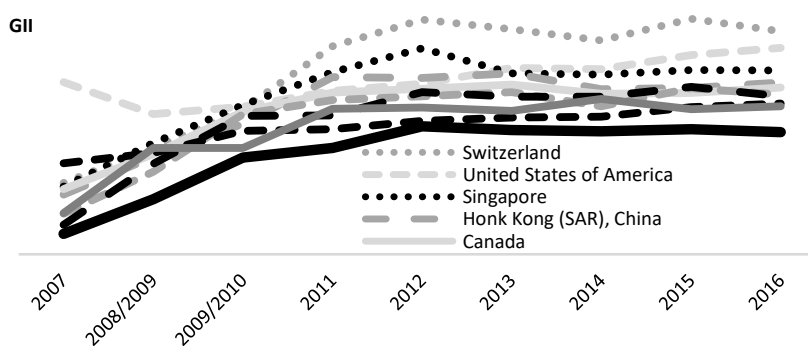

Fig. 1. The value of the innovation index GII in the EU against the background of world innovators in the years $2007 \div 2016$. Source: own study based on [11], [12]

The data show that in 2016, the group of most innovative countries was dominated by the European states, including those belonging to the European Union (figure 2). Among all European countries the most innovative are in sequence: Switzerland, Sweden and the United Kingdom, followed by Finland and the Netherlands. The index of innovation in these mentioned countries reached in 2016 a value of over 59 points out of 100 possible. These 5 countries were ahead of others such as Hong Kong, Japan or the Republic of Korea, whose indexes of innovation were above an average for all analysed countries.

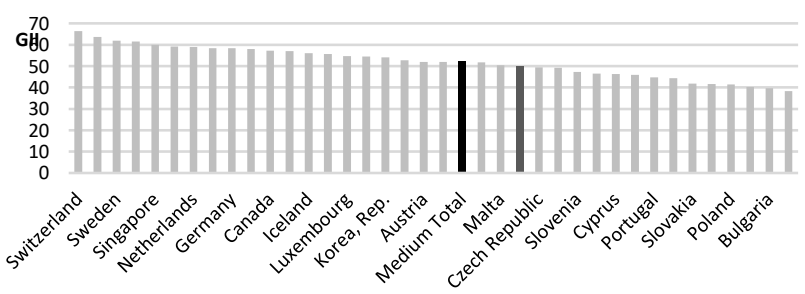

Fig. 2. GII innovation index in individual countries in 2016. Source: own study based on [11], [12]
Accordingly Greece, Bulgaria, Croatia, Poland, Lithuania and Slovakia ranked the lowest innovation index among EU countries and all analysed. Higher GII value than in listed countries, although below the average, was noted in the Czech Republic, Spain, Slovenia, Hungary, Cyprus, Italy, Portugal, as well as Latvia.

Further analysis was aimed at checking GII changes over 10 years (figure 3 ). In all analyzed countries, a positive average annual rate of change in the index over a decade was found in the study period. The dynamics of index changes was highest in Switzerland and Malta. The lowest dynamics were recorded in the USA and Japan, and from European countries - in Slovakia, Greece and France.

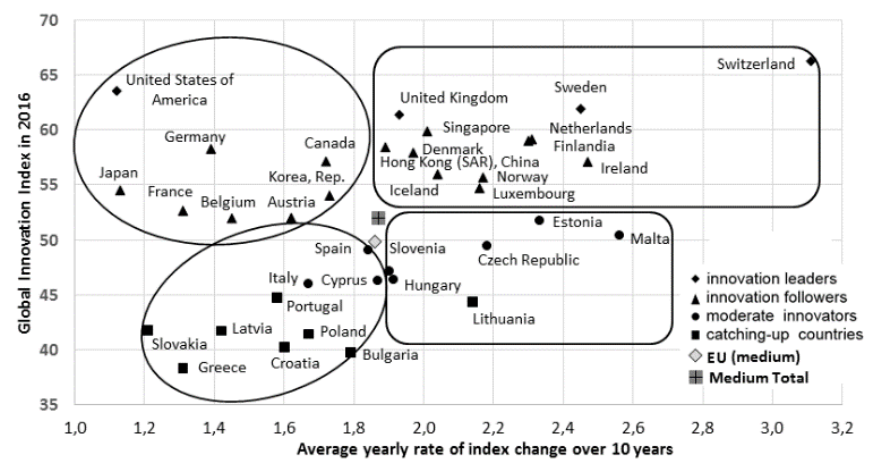

Fig. 3. GII index in 2016 and its average annual change over the period of 10 years $[2007 \div 2016]$ in selected countries. Source: own study based on [11], [12]

In the coordinate system on figure 3 compiles the values of the innovation index in 2016 with its annual average change over the period 2007-2016. The average values of these features for the $\mathrm{EU}$ as a whole and for all the surveyed countries were shown. The point of intersection of the index value with its change rate for the total surveyed states allowed to determine the boundaries of the four fields in which the groups of states were located.

The first group included countries whose index of innovation in 2016 and its average annual rate of change over the decade were higher than the overall average. Among these countries are: Switzerland, Sweden, the Netherlands, Finland, Ireland, Norway, Luxembourg, Iceland, Denmark, Singapore, the United Kingdom and Hong Kong.

The second group consisted of countries that had a high index of innovation (above the average), but its annual rate of change in the analyzed period was lower than the overall average. This group includes Canada, South Korea, France, Germany, Japan and the United States of America. Austria and Belgium are on a par with the overall average but above the EU average.

The third group comprises countries whose index of innovation was below the average in 2016 and its average annual growth rate over the decade has exceeded the average for all analyzed countries. Among the countries belonging to this group were Malta, Estonia, Lithuania, Slovenia, the Czech Republic, Hungary and almost equal Cyprus.

The last fourth group with low both: indexes of innovation and average annual growth rates included Spain, Italy, Portugal, Poland, Croatia, Latvia, Slovakia and Greece.

Comparisons of the GII index variance in the analyzed countries were also made using the arithmetic average and the standard deviation. By analyzing the distribution of GII values in time, it can be seen that the largest positive deviation from the mean value in a given year was recorded in Switzerland in 2015 and in the USA in 2007, while the greatest negative deviation - in Greece in 2012 (tab. 1). However, these were extreme values. Bypassing them in further analysis 4 key groups of countries with a similar index level to the arithmetic mean of a given year were identified.

Indeed, above the average for the period under review, the innovation index was in Switzerland, Sweden, the United Kingdom, the United States, and Finland. In the years 2013-2015 its value has also been high in the Netherlands, and in the years 2008-2012 in Singapore. In Germany from 2009/2010 index has decreased, as in Canada and Denmark.

Significant changes in the size of the innovation index have been demonstrated in Japan in the period considered, where its value in 2007 
was close to the leaders of innovators, while in 2012 the index fell below the average. Throughout the analyzed period, the index of innovation significantly below the average was recorded in Greece, Poland, Bulgaria and Croatia. Lithuania and Slovakia also got worse. In the last year of analysed period Latvia fall into the lower group as well.

Table 1. Diversification of innovation in selected countries according to their GII in the years $2007 \div 2016$. Source: own study based on [11], [12]

\begin{tabular}{|c|c|c|c|c|c|c|c|c|c|}
\hline $\begin{array}{c}\text { Specificatio } \\
n\end{array}$ & $\begin{array}{c}200 \\
7\end{array}$ & $2008 / 09$ & $2009 / 10$ & $\begin{array}{c}201 \\
1\end{array}$ & $\begin{array}{c}201 \\
2\end{array}$ & $\begin{array}{c}201 \\
3\end{array}$ & $\begin{array}{c}201 \\
4\end{array}$ & $\begin{array}{c}201 \\
5\end{array}$ & $\begin{array}{c}201 \\
6\end{array}$ \\
\hline Switzerland & 1 & 1 & 2 & 2 & 2 & 2 & 2 & 3 & 2 \\
\hline Sweden & 1 & 2 & 2 & 2 & 2 & 2 & 2 & 2 & 2 \\
\hline $\begin{array}{l}\text { United } \\
\text { Kingdom }\end{array}$ & 2 & 2 & 1 & 1 & 2 & 2 & 2 & 2 & 2 \\
\hline $\begin{array}{l}\text { United } \\
\text { States of } \\
\text { America }\end{array}$ & 3 & 2 & 2 & 1 & 1 & 2 & 2 & 2 & 2 \\
\hline Finland & 1 & 1 & 2 & 2 & 2 & 2 & 2 & 1 & 2 \\
\hline Netherlands & 1 & 1 & 1 & 1 & 1 & 2 & 2 & 2 & 1 \\
\hline Singapore & 1 & 2 & 2 & 2 & 2 & 1 & 1 & 1 & 1 \\
\hline Ireland & 1 & 1 & 1 & 1 & 1 & 1 & 1 & 1 & 1 \\
\hline $\begin{array}{l}\text { Hong Kong } \\
\text { (SAR), China }\end{array}$ & 1 & 1 & 1 & 2 & 1 & 1 & 1 & 1 & 1 \\
\hline Denmark & 1 & 1 & 2 & 1 & 1 & 1 & 1 & 1 & 1 \\
\hline Canada & 1 & 1 & 2 & 1 & 1 & 1 & 1 & 1 & 1 \\
\hline Germany & 2 & 2 & 1 & 1 & 1 & 1 & 1 & 1 & 1 \\
\hline Iceland & 1 & 1 & 1 & 1 & 1 & 1 & 1 & 1 & 1 \\
\hline Luxembourg & 1 & 1 & -1 & 1 & 1 & 1 & 1 & 1 & 1 \\
\hline Korea, Rep. & 1 & 1 & -1 & 1 & 1 & 1 & 1 & 1 & 1 \\
\hline Austria & 1 & 1 & 1 & 1 & 1 & -1 & 1 & 1 & 1 \\
\hline Japan & 2 & 1 & 1 & 1 & -1 & 1 & 1 & 1 & 1 \\
\hline France & 1 & 1 & 1 & -1 & -1 & 1 & 1 & 1 & 1 \\
\hline Norway & -1 & 1 & 1 & 1 & 1 & 1 & 1 & 1 & -1 \\
\hline Estonia & -1 & -1 & -1 & -1 & 1 & -1 & -1 & 1 & -1 \\
\hline Belgium & 1 & 1 & 1 & -1 & 1 & 1 & -1 & -1 & -1 \\
\hline Malta & -1 & -1 & -1 & -1 & 1 & -1 & -1 & -1 & -1 \\
\hline $\begin{array}{l}\text { Czech } \\
\text { Republic }\end{array}$ & -1 & -1 & -1 & -1 & -1 & -1 & -1 & -1 & -1 \\
\hline Spain & -1 & -1 & -1 & -1 & -1 & -1 & -1 & -1 & -1 \\
\hline Slovenia & -1 & -1 & -1 & -1 & -1 & -1 & -1 & -1 & -1 \\
\hline Portugal & -1 & -1 & -1 & -1 & -1 & -1 & -1 & -1 & -1 \\
\hline Italy & -1 & -1 & -2 & -2 & -2 & -1 & -1 & -1 & -1 \\
\hline Hungary & -1 & -2 & -1 & -1 & -1 & -1 & -2 & -2 & -1 \\
\hline Latvia & -2 & -2 & -2 & -2 & -1 & -1 & -1 & -1 & -2 \\
\hline Slovakia & -1 & -1 & -2 & -2 & -2 & -2 & -2 & -2 & -2 \\
\hline Lithuania & -2 & -2 & -1 & -2 & -2 & -2 & -2 & -2 & -2 \\
\hline Croatia & -2 & -2 & -2 & -2 & -2 & -2 & -2 & -2 & -2 \\
\hline Bulgaria & -2 & -2 & -2 & -2 & -2 & -2 & -2 & -2 & -2 \\
\hline Poland & -2 & -2 & -2 & -2 & -2 & -2 & -2 & -2 & -2 \\
\hline Greece & -2 & -2 & -2 & -2 & -3 & -2 & -2 & -2 & -2 \\
\hline
\end{tabular}

In further analysis, one of taxonomic methods was used. Comparison of the variance index of innovations in the years 2007-2016 by the Ward method showed the division of the examined countries into three groups, similar in terms of innovativeness (figure 4).

The first group included: Switzerland and Sweden, United Kingdom Germany and United States of America. Far from them are Finland, Netherlands, Singapore, Denmark, Hong Kong and Canada. These are the countries that can be described as innovation leaders.

The second group, with a significant index of innovation, which seeks to increase or maintain the value of this index year by year, comprises the following countries: South Ireland, Luxembourg, South Korea, Iceland, Norway, Japan, France, Austria, Belgium as well as more distant Estonia, Malta, the Czech Republic and Spain.

The third last group consists of 11 countries: Italy, Portugal, Slovenia, Hungary, Latvia, Lithuania, Slovakia as well as Bulgaria, Poland, Croatia and Greece. These are the countries with the lowest values of the index of innovation, not exceeding 48 points out of 100 in the analyzed years.

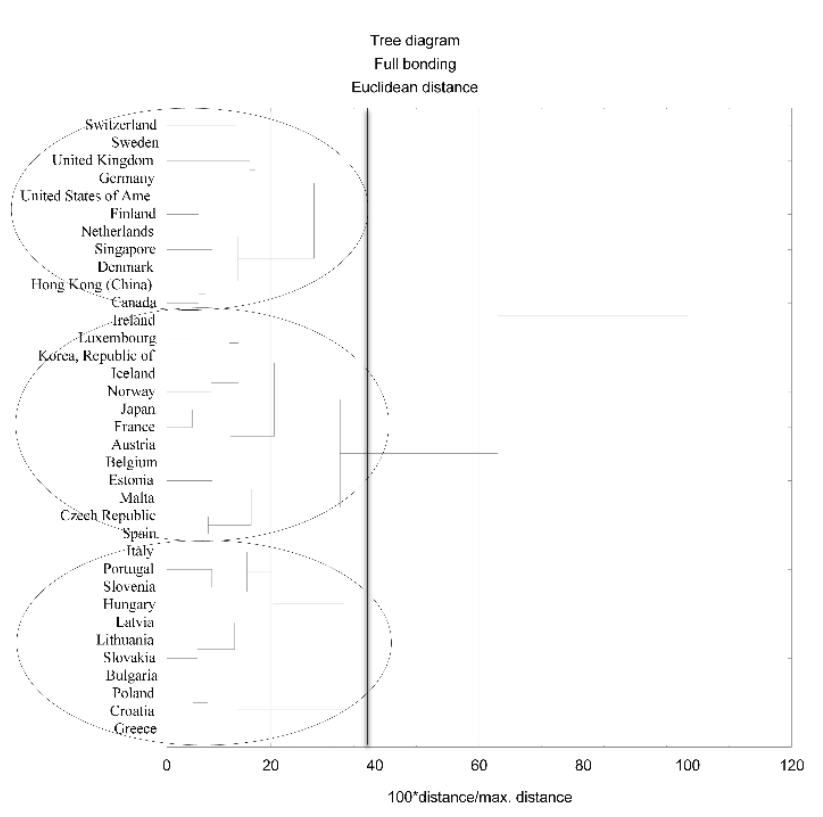

Fig. 4. Convergence of countries in terms of the GII innovation index in the years $2007 \div 2016$. Source: own study based on [11], [12]

The European Institute of Management provides data on the innovativeness of economies, taking into account division into indicators of innovative position and ability to innovate $[11,12]$. Analysis of institute data indicated not only large differences in the level of innovation across countries, but also significant changes in some of them from 2011 to 2016 (tab. 2).

The leader of the selected countries during the analyzed period was of course Switzerland taking first place just before Sweden. It should be noted, however, that in Switzerland, despite a high Global Index of Innovation, the deterioration of innovation input sub-index has been noticeable (within five years this county changed position from 3 to 6). The United States of America significantly improve its ability to innovation changing ranking position from 11 in 2011 to 3 in 2016. Thanks to it USA rank 4 th in the global index innovation ranking immediately after the UK, which much improved all innovation indicators in the period under consideration and changed position (for sub-index of innovation output from 9 to 4 as well as innovation input - from 10 to 7).

During the period under review, the positions of Singapore and Hong Kong has decreased very much, although they still had the highest innovation input sub-indexes. In 2016 they amounted sequentially to 72.9 and 69.1. The fall in all indicators recorded in Canada, which reduced its position from 8th to 15th place. It also lowered the position of Denmark (from 6th place to 8 th) and Norway (from 18th to 22nd place).

Tab. 2. Innovation rating, innovation output and innovation input in selected countries in 2016 compared to 2011. Source: own study based on [11], [12]

\begin{tabular}{|c|c|c|c|c|c|c|c|c|c|}
\hline \multirow{3}{*}{ Country } & \multicolumn{3}{|c|}{$\begin{array}{l}\text { Global Index } \\
\text { Innovation }\end{array}$} & \multicolumn{3}{|c|}{$\begin{array}{l}\text { Innovation Output } \\
\text { Sub-Index }\end{array}$} & \multicolumn{3}{|c|}{$\begin{array}{l}\text { Innovation Input } \\
\text { Sub-Index }\end{array}$} \\
\hline & value & \multicolumn{2}{|c|}{$\begin{array}{c}\text { ranked } \\
\text { position }\end{array}$} & value & \multicolumn{2}{|c|}{ ranked position } & value & \multicolumn{2}{|c|}{$\begin{array}{c}\text { ranked } \\
\text { position }\end{array}$} \\
\hline & \multicolumn{2}{|c|}{2016} & $\begin{array}{c}201 \\
1\end{array}$ & \multicolumn{2}{|c|}{2016} & 2011 & \multicolumn{2}{|c|}{2016} & 2011 \\
\hline Switzerland & 66.3 & 1 & 1 & 64.2 & 1 & 2 & 68.4 & 6 & 3 \\
\hline Sweden & 63.6 & 2 & 2 & 58.7 & 2 & 1 & 68.5 & 5 & 5 \\
\hline $\begin{array}{l}\text { United } \\
\text { Kingdom }\end{array}$ & 61.9 & 3 & 10 & 56.3 & 4 & 9 & 67.5 & 7 & 10 \\
\hline $\begin{array}{l}\text { United States } \\
\text { of America }\end{array}$ & 61.4 & 4 & 7 & 54.1 & 7 & 5 & 68.7 & 3 & 11 \\
\hline Finland & 59.9 & 5 & 5 & 51.3 & 10 & 6 & 68.5 & 4 & 6 \\
\hline Singapore & 59.2 & 6 & 3 & 45.4 & 20 & 17 & 72.9 & 1 & 1 \\
\hline Ireland & 59.0 & 7 & 13 & 55.6 & 5 & 22 & 62.4 & 16 & 4 \\
\hline Denmark & 58.5 & 8 & 6 & 49.8 & 13 & 7 & 67.1 & 8 & 7 \\
\hline Netherlands & 58.3 & 9 & 9 & 52.5 & 9 & 3 & 64.0 & 12 & 16 \\
\hline Germany & 57.9 & 10 & 12 & 54.0 & 8 & 4 & 61.9 & 18 & 21 \\
\hline Korea, Rep. & 57.1 & 11 & 16 & 50.8 & 11 & 11 & 63.5 & 13 & 17 \\
\hline Luxembourg & 57.1 & 12 & 17 & 57.6 & 3 & 25 & 56.6 & 23 & 9 \\
\hline Iceland & 56.0 & 13 & 11 & 55.3 & 6 & 13 & 56.6 & 24 & 13 \\
\hline $\begin{array}{l}\text { Hong Kong } \\
\text { (SAR), China }\end{array}$ & 55.7 & 14 & 4 & 42.2 & 25 & 12 & 69.1 & 2 & 2 \\
\hline Canada & 54.7 & 15 & 8 & 44.0 & 23 & 10 & 65.4 & 10 & 8 \\
\hline
\end{tabular}




\begin{tabular}{|l|c|c|c|c|c|c|c|c|c|}
\hline Japan & 54.5 & 16 & 20 & 43.0 & 24 & 26 & 66.0 & 9 & 18 \\
\hline France & 54.0 & 18 & 22 & 45.5 & 19 & 21 & 62.6 & 15 & 23 \\
\hline Austria & 52.6 & 20 & 19 & 44.4 & 22 & 23 & 60.9 & 19 & 19 \\
\hline Belgium & 52.0 & 23 & 24 & 45.7 & 18 & 28 & 58.2 & 20 & 22 \\
\hline Norway & 52.0 & 22 & 18 & 42.0 & 26 & 18 & 62.0 & 17 & 14 \\
\hline Estonia & 51.7 & 24 & 23 & 49.3 & 14 & 20 & 54.2 & 27 & 24 \\
\hline Malta & 50.4 & 26 & - & 49.9 & 12 & - & 51.0 & 35 & - \\
\hline $\begin{array}{l}\text { Czech } \\
\text { Republic }\end{array}$ & 49.4 & 27 & 27 & 44.5 & 21 & 24 & 54.3 & 26 & 26 \\
\hline Spain & 49.2 & 28 & 32 & 41.1 & 28 & 34 & 57.3 & 22 & 29 \\
\hline Italy & 47.2 & 29 & 35 & 40.3 & 31 & 39 & 54.1 & 28 & 37 \\
\hline Portugal & 46.4 & 30 & 33 & 39.8 & 32 & 36 & 53.1 & 30 & 34 \\
\hline Cyprus & 46.3 & 31 & 28 & 40.8 & 29 & 27 & 51.9 & 33 & 30 \\
\hline Slovenia & 46.0 & 32 & 30 & 38.9 & 33 & 30 & 53.0 & 31 & 32 \\
\hline Hungary & 44.7 & 33 & 25 & 40.5 & 30 & 16 & 48.9 & 38 & 33 \\
\hline Latvia & 44.3 & 34 & 36 & 38.9 & 34 & 45 & 49.7 & 36 & 38 \\
\hline Lithuania & 41.8 & 36 & 40 & 32.3 & 41 & 59 & 51.2 & 34 & 39 \\
\hline Slovakia & 41.7 & 37 & 37 & 35.4 & 38 & 54 & 48.0 & 42 & 35 \\
\hline Bulgaria & 41.4 & 38 & 42 & 37.5 & 35 & 43 & 45.3 & 49 & 47 \\
\hline Poland & 40.2 & 39 & 43 & 31.7 & 46 & 55 & 48.7 & 39 & 41 \\
\hline Greece & 39.8 & 40 & 63 & 30.1 & 49 & 72 & 49.4 & 37 & 50 \\
\hline Croatia & 38.3 & 47 & 44 & 30.2 & 48 & 48 & 46.4 & 45 & 45 \\
\hline
\end{tabular}

\section{$(-)$ lack of data}

Improvements in the ranking were recorded in most of the new Member States of the European Community, despite their still weak position in relation to the other analysed countries. These countries included Poland, Greece, Bulgaria, Lithuania and Latvia. Higher position occupied also the other members of the EU, like Ireland, Germany, Luxembourg, France, Belgium, Spain and the Asian countries, such as Republic of Korea and Japan.

The factors influencing the value of indices of innovation achieved by each country were also analysed (fig. 5). Among the areas determining the abilities to innovation, the highest values in 2016 were obtained by the institutions. The political, regulatory and business environment was highest rated in Singapore (94.9 points), Finland (94.3 points) and Hong Kong ( 92.8 points), while the lowest - in Bulgaria (67.8 points) and Greece (67.1 points). In the case of Singapore and Finland, the value of this ratio in 2011 increased accordingly by 4.5 and 5.1 points, while in Hong Kong this value remained at the same level. The biggest drop in the indicator representing institutions was recorded in Bulgaria (6.7 points), followed by the Czech Republic (6.5 points) and Luxembourg (6.2 points). The innovativeness of the institutions in Spain was the most improved (growth rate was 6.4 points).
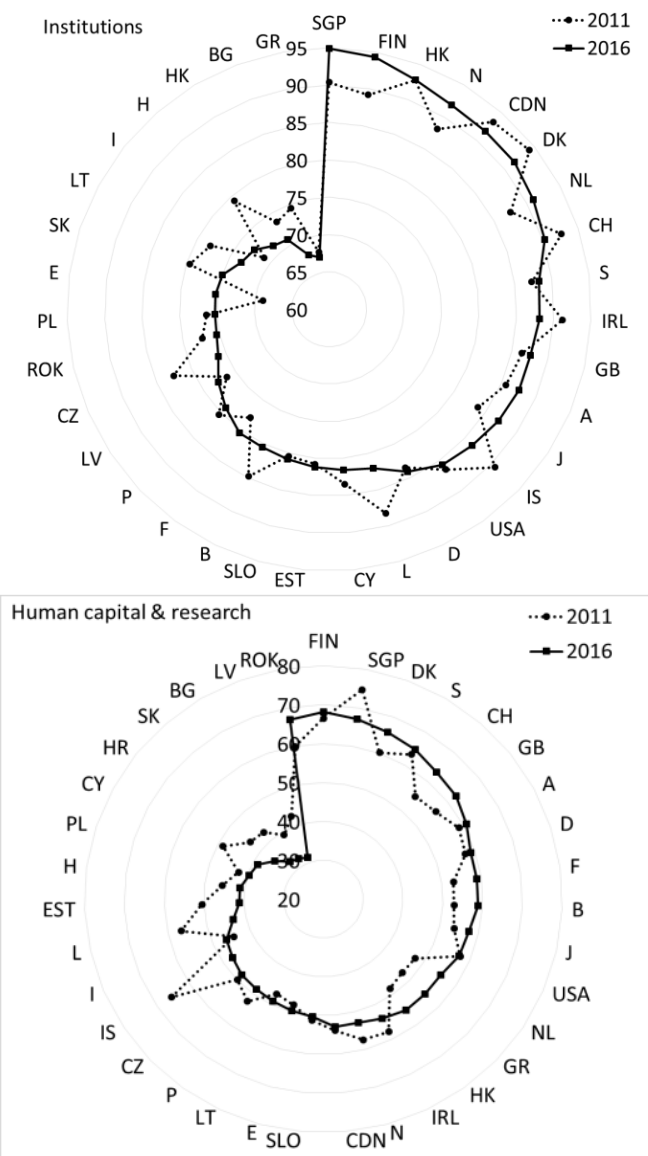
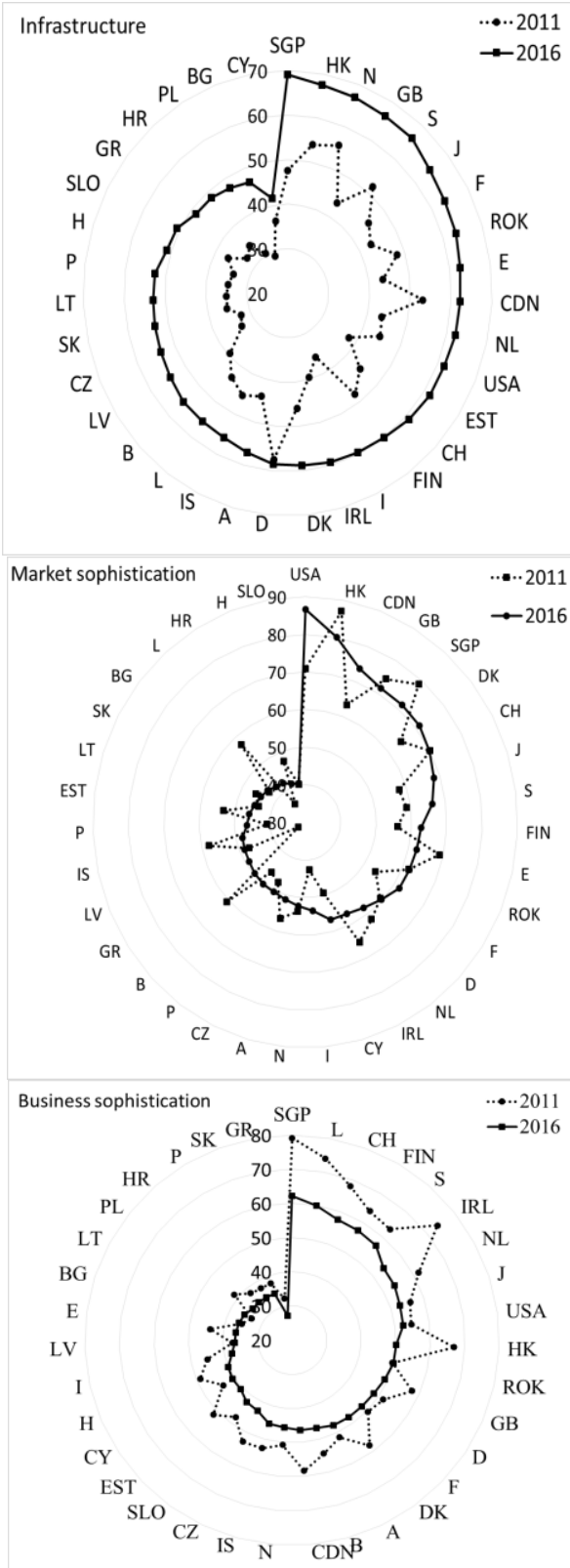

Fig. 5. Average index of countries' ability to innovation by areas in 2011 and 2016. Source: own study based on [11], [12]

The best in terms of innovation in the area of human capital and research were Finland and Singapore, reaching over 67 points out of 100 possible. Singapore, the only one among the dominant countries in this area, recorded a decrease (by 7.6 points) compared to 2011, taking second place. The largest falls of analysed indicator during the period considered were affected by Iceland: (18.4 points), Luxembourg (13.3 points) and Latvia (11.4 points). The highest increase was in Switzerland (8.2 points), Greece (7.9 points), the Netherlands (7.7 points), and South Korea. (7 points).

In the area of infrastructure, the highest indexes were, like in earlier areas, Singapore (69.1 points). Similar results were obtained in this case Hong Kong (67.5 points) and Norway (67 points). Cyprus was the weakest (41.6 points). In this area, the indices of all analysed countries have increased. The highest increase was recorded in Estonia and Italy (over 23.5 points), while the lowest in Germany (by 1 point).

The United States of America ranked highest in terms of market development (reaching 86.6 points). This value has grown over 5 years by 15.7 points. Hong Kong also achieved a high value in this area ( 80 points), despite its decline by over 7 points in the period under review. In the development of the market in 2016, the least was evaluated Slovenia ( 40.5 points, an increase of 0.2 points) and Hungary, where the indicator fell by over 15 points to the level of 41 points.

The largest decreases in the value of indicators took place in the analysed years in the field of business environment. Only three of the 35 selected countries have experienced an increase in the value of this indicator. That 
was: South Korea (by 0.3 points), Bulgaria (by 0.8 points) and Lithuania (by 2.4 points). Other countries have been rated less than in 2011 in this area. The biggest declines, despite still high values, were reported in Ireland (20 points), Singapore (17 points) and Hong Kong (16.7 points). The analysis of areas corresponding to the country's innovation position index (figure 6) shows that Switzerland is leading in terms of knowledge and technology (67 points) followed by Sweden (63.7 points) and Ireland (57.9 points)

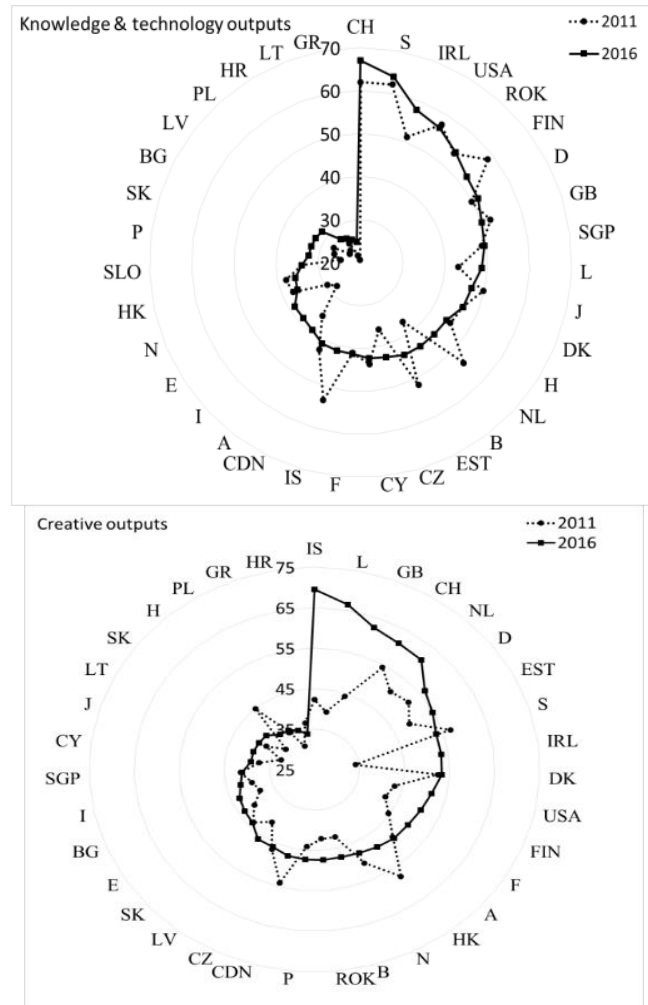

Fig. 6. Average index of innovation position of countries in particular areas in 2011 and 2016. Source: own study based on [11], [12]

The weakest (below 28 points) are Poland, Croatia, Lithuania and Greece. In terms of creativity, Iceland occupies the first position (69.5 points) and behind this country Luxembourg ( 66.4 points). The weakest, in the case of knowledge and technology, fall in Greece, Poland and Croatia. Iceland and Luxembourg have increased creative outputs by about 27 points in 5 years, while Hong Kong and Hungary significantly reduced it (by over 8 points).

\section{Conclusions}

In the industrial age, the competitiveness of economies depended on the size of the resources of physical goods. Afterwards, sustainability issues came into play [13], and human resources became important. At present, economic development is largely dependent on intangible factors related to knowledge. Knowledge should be skillfully extended and applicate to better use of material resources. In this way, the competitive advantage of the developed countries is being built.

Using multiple statistical methods there were identified in the article groups of countries, which can be counted to: innovation leaders, the countries following them, the moderating innovators, and those catching up. Each of these groups consists of very different countries in terms of geographic location, size and culture. Innovative leaders dominate the northern hemisphere. Economically developed countries achieve higher innovation rates. In turn, the research confirms that the higher the innovativeness in a country, the better it develops.
Implementing innovation is expensive. It is apparent that this process has been halted in countries with transitional economic problems (for example in Greece). Countries that can count on financial flows generally improve their position (like new EU members).

The undisputed leader of innovation, which is still improving it, is Switzerland. This small non-EU country is a well-organized organism, that is not susceptible to global crises and develops a knowledge-based economy. It can be a great example of an innovator, primarily in the area of knowledge and technology. The Swiss economy is driven by highly developed: precision industry, banking and medicine.

\section{References}

[1] J. Czerniak, ed., „Innovation in Poland and the world economy”, Lublin: Scientific Circle of the Faculty of Economics UMCS p. 7, 2013. (Polish)

[2] J. Staśkiewicz, „Evaluation of national innovative capacity of European Union member countries in 2000-2009", Studies and works of the Faculty of Economic, Sciences and Management of the University of Szczecin, no. 25, p. 105-122, 2012. (Polish)

[3] The World Competitiveness Report 1994, Lausanne: World Economic Forum, p. 18, 1994.

[4] M. Grzebyk and Z. Kryński, „Competition and business competitiveness. The theoretical approach" in Social inequalities and economic growth, Scientific papers of the University of Rzeszow, no. 20, p.111, 2011. (Polish)

[5] E. Okoń-Horodyńska, „What about the National System of Innovation in Poland?" in The role of Polish science in increasing the innovativeness of the economy, E. Okoń-Horodyńskiej, ed., Warszawa: Polish Economic Association, p. 79, 2004. (Polish)

[6] M. Stec, „Innovation of European Union countries”, National Economy, no. 11-12, p. 59, 2009. (Polish)

[7] K. Krzyżanowska, „Economic and social determinants of innovation in teamwork in agriculture”. Warszawa: Main School of Rural Economy, p. 34, 2016. (Polish)

[8] L. Zienkowski, „Does Poland's macroeconomic policy contain the paradigm of innovation growth of the economy?" in The role of Polish science in increasing the innovativeness of the economy, E. OkońHorodyńska, ed., Warszawa: Polish Economic Association, pp. 54-62, 2004. (Polish)

[9] A. Olszańska, „Livestock market in Poland (1955-2010) structural changes, concentration of production and supply fluctuations", Wroclaw: Wroclaw University of Economics, p. 160, 2012. (Polish)

[10] http://home.agh.edu.pl/ mmd/_media/dydaktyka/adp/analiza_ skupien.pdf [Accessed: 29-Jun-2017].

[11] S. Dutta, B. Lanvin, and S. Wunsch-Vincent, ed., "The Global Innovation Index 2016. Winning with Global Innovation", Ithaca, Fontainebleau, and Geneva: Cornell University, INSEAD, and the World Intellectual Property Organization, 2016.

[12] S. Dutta, INSEAD, ed., "The Global Innovation Index 2011 Accelerating Growth and Development". Fontainebleau: INSEAD and Knowledge Partners, 2011.

[13] A. Mazur, A. Stachowiak, H. Gołaś "Research on the level of organizational maturity in the context of sustainable resources management", Proceedings of 20163rd International Conference on Social Science (ICSS 2016), vol. 1, Shanghai, China: DEStech Publications, Inc. Lancaster, USA, December 9-11, 2016. 